\title{
Long-term risks of bisphosphonate therapy
}

\section{Riscos do tratamento a longo prazo com bisfosfonatos}

Nelson B. Watts'
${ }^{1}$ Mercy Health Osteoporosis and Bone Health Services, Cincinnati, United States
The objective this study was to summarize long-term risks associated with bisphosphonate therapy. Search of relevant medical publications for data from clinical trials, trial extensions, observational studies and post-marketing reports. Trial extensions and modifications did not reveal significant long-term safety issues. Observational data suggest at least as many benefits as risks. Post-marketing reports of musculoskeletal pain, osteonecrosis of the jaw and atypical femur fractures have been widely circulated in the lay press. Most focus on long-terms risks has been on osteonecrosis of the jaw and atypical femur fractures which occur in patients who have not received bisphosphonate therapy but may be more frequent (though still uncommon) in patients who have been on treatment for 5 years or longer. Lower-risk patients may be able to stop treatment after 3-5 years for a "drug holiday," which mitigates these long-term risks; for higher risk patients, therapy through 6-10 years appears to be advisable and offers more benefits than risks. Arq Bras Endocrinol Metab. 2014;58(5):523-9

\section{Keywords}

Bisphosphonates; alendronate; ibandronate; risedronate; zoledronate; fractures; osteonecrosis

\section{RESUMO}

O objetivo deste estudo foi resumir os riscos associados ao tratamento a longo prazo com bisfosfonatos. Foram pesquisadas as publicações médicas relevantes incluindo ensaios clínicos, extensões de ensaios clínicos, estudos observacionais e relatórios pós-comercialização (vigilância farmacológica). As extensões e modificações de ensaios clínicos não indicaram nenhuma situação de alarme quanto à segurança dos bisfosfonatos a longo prazo. Dados observacionais sugerem pelo menos tantos benefícios quanto riscos. Entretanto, relatos pós-comercialização de dor musculoesquelética, osteonecrose da mandíbula e fraturas de fêmur atípicas foram amplamente divulgados na imprensa leiga. 0 foco nos riscos a longo prazo do tratamento com bisfosfonatos tem sido pincipalmente a osteonecrose da mandíbula e as fraturas atípicas de fêmur. Essas últimas, embora mais frequentes (ainda que pouco comuns) em pacientes que receberam tratamento com bisfosfonatos por 5 anos ou mais, podem ocorrer em indivíduos não tratados com esses medicamentos. Pacientes com baixo risco de fratura podem potencialmente parar o tratamento depois de 3 a 5 anos ( "drug holiday"). Esse procedimento reduz os riscos desses medicamentos a longo prazo. Não obstante, nos pacientes de maior risco a terapia por 6 a 10 anos parece ser aconselhável e oferece mais benefícios do que riscos. Arq Bras Endocrinol Metab. 2014;58(5):523-9

\section{Descritores}

Bisfosfonatos; alendronato; ibandronato; risedronato; zoledronato; fraturas ósseas; osteonecrose
Correspondence to: Nelson B. Watts Mercy Health Osteoporosis and Bone Health Services 4760 E. Galbraith Rd., Suite 212 45236 - Cincinnati OH, United States nelson.watts@hotmail.com

Received on Apr/22/2014 Accepted on May/12/2014 DOI: 10.1590/0004-2730000003308

\section{INTRODUCTION}

B isphosphonates were discovered in the mid 1800s and continue to be used commercially as anti-scaling agents. In the late 1960s they began to be used for treatment of metabolic bone diseases including hete- rotopic ossification, fibrous dysplasia, osteogenesis imperfecta, Paget's disease of bone, hypercalcemia due to a variety of causes, bone loss due to a variety of causes, destructive arthropathy and skeletal involvement with metastatic cancer or multiple myeloma (1). In the Uni- 
ted States, four bisphosphonates are approved for the prevention and/or treatment of postmenopausal osteoporosis, osteoporosis in men and osteoporosis due to long-term glucocorticoid therapy. Alendronate and risedronate can be given orally daily, weekly or monthly, zoledronate is a once-yearly intravenous infusion and ibandronate can be given either orally (monthly) or intravenously (every third month). Bisphosphonates bind strongly to hydroxyapatite crystals in bone (zoledronate most strongly, risedronate least strongly; alendronate and ibandronate have intermediate affinity for bone). Drug that does not bind with bone is rapidly excreted by the kidneys. In the process of bone resorption, bisphosphonates are released from the bone and enter the osteoclasts, causing loss of resorptive function and accelerating apoptosis. There is a rapid and substantial decrease in bone turnover markers with a maximum effect in 3-6 months and modest increases in bone density in the first few years of treatment (3\%-5\%) that then plateau. With continued treatment, the new steady state is maintained for 10 years $(2,3)$ and probably longer.

\section{BENEFITS OF TREATMENT WITH BISPHOSPHONATES}

Bisphosphonates have proven efficacy for prevention of bone loss due to aging, estrogen deficiency and glucocorticoid use. Three of the four (alendronate, risedronate and zoledronate) have been shown in placebo-controlled trials to prevent fractures of the spine, hip and other non-vertebral sites (4-6). Because of this "broad-spectrum" antifracture efficacy, bisphosphonates have been the agents of choice for most patients with osteoporosis. Table 1 shows the current indications for these agents and the available dosing forms.

\section{SHORT-TERM SIDE EFFECTS}

Orally-administered bisphosphonates are usually well tolerated but may irritate the esophagus and should not be used by patients who cannot remain upright, who have active upper gastrointestinal symptoms or delayed esophageal emptying. Up to a third of patients receiving their first intravenous dose of zoledronate or monthly oral dose of ibandronate or risedronate experience one or more symptoms of acute-phase reactions (fever, muscle aches etc.) (7-9) but these rarely recur with repeated administration. Hypocalcemia may occur but is usually mild and not clinically recognized (10). Iritis has been described with bisphosphonates (more with IV than oral) but is rare $(<1$ per 1,000$)$.

Although there is no evidence of renal toxicity from oral bisphosphonates, the only route of elimination is by the kidneys, so they should be used with caution if at all by patients with reduced kidney function (alendronate should not be used if GFR $<35 \mathrm{~mL} / \mathrm{min}$ for alendronate, risedronate and ibandronate require GFR of at least $30 \mathrm{~mL} / \mathrm{min}$ ). Renal toxicity may occur with rapid IV administration of zoledronate; its use is contraindicated for patients with creatinine clearance under $35 \mathrm{~mL} / \min (11,12)$.

\section{LONG-TERM STUDIES WITH BISPHOSPHONATES}

Bisphosphonates used in the US were approved based on placebo-controlled trials of 3-4 years' duration. Several of these studies have been extended, with two alendronate cohorts followed for 10 years $(2,3)$, risedronate cohorts followed for 4 (13) and 7 years (14) and zoledronate cohorts followed for 6 years (15). No new safety concerns have emerged. Although there have been some concerns about possible oversuppres-

Table 1. Names and indications for nitrogen-containing bisphosphonates in Brazil

\begin{tabular}{|c|c|c|c|c|c|}
\hline \multirow{2}{*}{ Name } & \multicolumn{2}{|c|}{ Postmenopausal osteoporosis } & \multicolumn{2}{|c|}{ Glucocorticoid-induced osteoporosis } & \multirow{2}{*}{ Men } \\
\hline & Prevention & Treatment & Prevention & Treatment & \\
\hline \multirow{2}{*}{$\begin{array}{l}\text { Alendronato (Fosamax }{ }^{\circledR} \text {, } \\
\text { Alendil }^{\circledR} \text {, generic) }\end{array}$} & 5 mg daily & 10 mg daily & & 10 mg daily & 10 mg daily \\
\hline & 35 mg weekly & 70 mg weekly & & & 70 mg weekly \\
\hline \multirow[t]{2}{*}{ Ibandronato (Boniva ${ }^{\circledR}$ ) } & & 150 mg monthly & & & \\
\hline & & 3 mg IV every third month & & & \\
\hline \multirow[t]{3}{*}{ Risedronato (Actonel ${ }^{\circledR}$ ) } & 5 mg daily & 5 mg daily & $\sqrt{ }$ & $\sqrt{ }$ & 5 mg daily \\
\hline & 35 mg weekly & 35 mg weekly & & & 35 mg weekly \\
\hline & 150 mg monthly & 150 mg monthly & & & 150 mg monthly \\
\hline Risedronato (generic) & 35 mg weekly & 35 mg weekly & & & \\
\hline Zoledronic acid (Aclasta $\left.{ }^{\circledR}\right)$ & 5 mg IV yearly & 5 mg IV yearly & 5 mg IV yearly & 5 mg IV yearly & 5 mg IV yearly \\
\hline
\end{tabular}


sion of bone turnover, iliac crest biopsies after up to 10 years of treatment have not shown oversuppression (2).

Since their approval and wide-spread use, a number of potential safety concerns have been identified but with no clear cause-and-effect relationship but at least some evidence of increased risk (albeit rare) with therapy of 5 years or longer. These include musculoskeletal pain, atrial fibrillation (AF), esophageal cancer, osteonecrosis of the jaw $(\mathrm{ONJ})$ and atypical femur fractures (AFF). The latter two have been subject to close scrutiny and widespread discussion in the medical literature and in the lay press.

\section{MUSCULOSKELETAL PAIN}

The label for all bisphosphonates lists musculoskeletal pain as a potential side effect. The US FDA received 117 reports of severe musculoskeletal pain (bone, joint and/or muscle pain) between 1995 and 2005 in adults on bisphosphonates (16). Symptoms may occur at any point after starting bisphosphonate therapy, improved promptly in some patients after discontinuation of the drug but many patients experienced a gradual or incomplete resolution of symptoms (16). The mechanism for this effect is not known and evidence supporting a causal relationship between musculoskeletal pain (a common problem in this age group) and bisphosphonate use is lacking. At present, the FDA recommends instructing patients to alert their physician if such symptoms occur for consideration of stopping the medication.

\section{ATRIAL FIBRILLATION}

In the HORIZON Pivotal Fracture Trial (PFT), more subjects had atrial fibrillation (AF) as a serious adverse event in the zoledronate group (1.3\%) compared with the placebo group $(0.5 \%)(6)$. It was unclear if this imbalance was causally related to the medication or simply a chance finding. This occurrence of AF did not seem to be associated with the timing of the infusion, the acute phase reaction following the infusion or any acute electrolyte imbalance. No increase in the rate of AF was noted in a smaller and shorter study (17) nor was an increase in AF noted in the oncology trials of zoledronate, using a dose of zoledronate 10-times higher than is used to treat osteoporosis.

Retrospective analysis alendronate and risedronate data do no support an association of atrial fibrillation with bisphosphonate use. Several larger observational studies have been published with mixed results (18-21). The information currently available does not show a consistent association and the overall evidence does not suggest causality - there is no convincing mechanism to account for this effect, which seems to be independent of the dose and duration of therapy. At the present time, the US Food and Drug Administration (FDA) recommends that physicians not alter their prescribing patterns for bisphosphonates while it continues to monitor post-marketing reports of AF in such patients.

\section{ESOPHAGEAL CANCER}

The FDA has received reports of 23 cases of esophageal cancer among patients receiving oral bisphosphonate therapy, described in a letter to the editor by Wysowski and cols. (22). In addition, 31 cases of esophageal cancer from Europe and Japan have been reported in patients after using oral bisphosphonates (22). These report did not provide information regarding risk factors for esophageal cancer or the expected incidence of esophageal cancer in this age group (23) and did not include a control group (24). Two other reports, one from European national registries and the second from the US Medicare database, have not shown an increased risk of esophageal cancer among individuals receiving oral bisphosphonates compared with those who were not $(25,26)$. Also, the time from exposure to diagnosis was brief and hence not consistent with a causal relationship $(27,28)$. Later reports have not provided additional clarity $(29,30)$. Although further studies looking at the potential risk for carcinogenicity are needed, the current data do not support a causal association between oral bisphosphonates and esophageal carcinoma.

\section{OSTEONECROSIS OF THE JAW}

In 2003, a letter to the editor reported osteonecrosis of the jaw $(\mathrm{ONJ})$ in 36 patients with advanced cancer who were being treated with high doses of intravenous bisphosphonates (approximately 10 times higher than the doses used to treat osteoporosis) (31). Subsequent reports $(32,33)$ included patients receiving lower doses of bisphosphonates for treatment of osteoporosis, but, to date, well over $90 \%$ of reported cases have been in cancer patients. This subject was extensively addressed by a Task Force of the American Society for Bone and Mineral Research (34). 
This condition has received considerable public exposure which caused misconceptions among medical and dental professionals as well as the public regarding the seriousness and frequency of this condition. Some patients decided to stop bisphosphonate treatment although they were at high risk of fracture and low risk of ONJ.

$\mathrm{ONJ}$ is a clinical diagnosis: exposed necrotic bone in the maxillo-facial region, not healing after 6 to 8 weeks in patients with no history of craniofacial radiation (34). The bone may be yellow or white, the borders smooth or ragged. ONJ often follows an invasive procedure, such as dental extraction, or occurs in patients with poorly-fitting dentures or bony exostoses. There may be pain, swelling, paresthesias, drainage, soft tissue ulceration, sinus tracks and loosening of teeth but many patients are asymptomatic (33). Some lesions heal slowly or not at all, but healing has been reported (35) and is probably the rule rather than the exception. ONJ has been seen in subjects not using bisphosphonates, but the background incidence is not known.

ONJ was not identified prospectively in any of the clinical trials that included over 60,000 patient-years in studies for osteoporosis or Paget's disease (36). Retrospective review of records from the HORIZON trial with IV zoledronate for osteoporosis, 2 cases of ONJ were identified: one who received zoledronate and one who received placebo (37). It is estimated that there have been over 200 million prescriptions in the US for oral bisphosphonates and over 6 million patients treated with IV bisphosphonates for cancer world-wide (38). Epidemiologic data suggest an incidence of ONJ in oral bisphosphonate users ranging from $1: 10,000$ to $1: 250,000$ (34).

A causal link between bisphosphonate use and ONJ is likely but has not been conclusively established. ONJ has also been seen in patients receiving high-dose denosumab for treatment of advanced cancer spread to bone (39). Possible mechanisms include over-suppression of bone turnover (failure of osteoclasts to remove diseased necrotic bone) or interference with clearance of microfilms.

The American Society for Bone and Mineral Research Task Force performed a comprehensive review (34) and the American Dental Association published guidelines in 2011 (40). Patients receiving bisphosphonates should be informed that there are risks of any treatment, including a low risk of ONJ with long-term therapy. Regular dental visits and maintenance of good oral hygiene including routine dental cleaning and nee- ded restorative procedures are important. Ideally, patients who need invasive dental procedures should have procedures done and healing complete before starting bisphosphonate therapy, if circumstances permit. Patients already taking a bisphosphonate may elect to take some time off therapy, though there is no evidence that this will improve outcomes.

\section{"ATYPICAL" FEMUR FRACTURES}

Although bisphosphonates reduce the rates of fractures due to osteoporosis, reports have suggested a link between bisphosphonate use and the development of so called "atypical" insufficiency fractures. Table 2 compares and contrasts "typical" and "atypical" femur fractures. Proximal femur fractures (hip) due to osteoporosis have no warning symptoms, are unilateral (on the side of a fall), have an acute angle and may be comminuted. Atypical fractures are often preceded by weeks of months of prodromal pain in the thigh or groin, require little or no trauma (Figure 1). Thirty percent of atypical fractures are bilateral. The location is in the subtrochanteric region of the femoral shaft. They are transverse or oblique angle with a medial spike and little or no comminution. They begin as a localized periosteal reaction of the lateral cortex. Cortical bone is unusually thick (and this is not a something that bisphosphonates do) and healing is often delayed.

Bone biopsies in such patients often show severely reduced bone turnover (57), although I have seen a
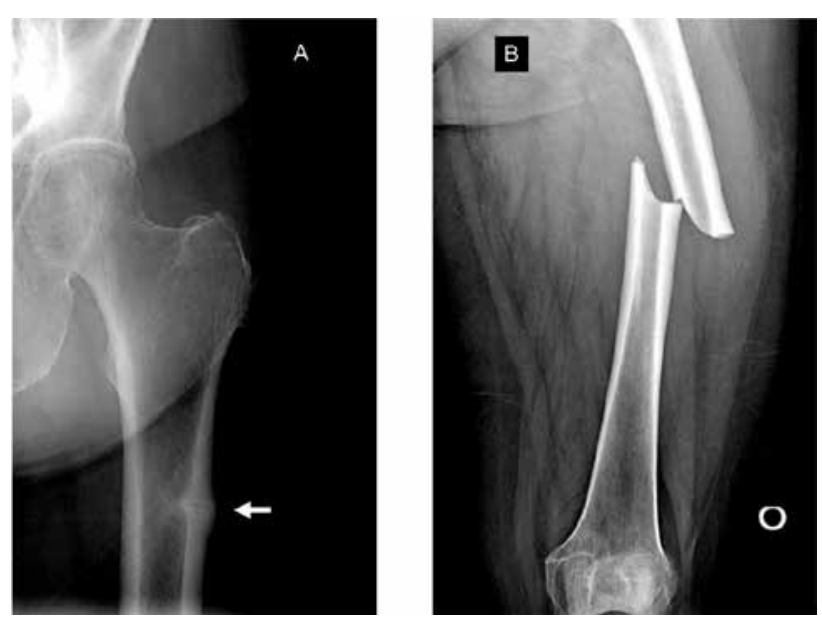

Figure 1. X-rays showing an impending femoral shaft fracture $(\mathbf{A})$ and a representative "atypical" diaphyseal femoral fracture with lateral cortical thickening and a lucency appearing like a "beak" and (B) with thickened cortices and a medial spike. From (56), (CS The Endocrine Society, used with permission. 
Table 2. Features of typical and atypical femur fractures

\begin{tabular}{ll}
\hline Typical femur fractures & Atypical femur fractures \\
\hline - No warning symptoms & - Prodromal thigh or groin pain \\
- Caused by a fall & - Little or no trauma* \\
- Unilateral & - $30 \%$ bilateral \\
- Proximal & - Subtrochanteric location ${ }^{\star *}$ \\
- Acute angle (femoral neck, intertrochanteric) & - Transverse/oblique angle, medial spike \\
- May be comminuted & - Little or no comminution \\
& - Begin as a localized periosteal reaction of the lateral cortex* \\
\hline
\end{tabular}

* Major features; four of five required by the ASBMR Task Force. Shane E, Burr D, Abrahamsen B, Adler RA, Brown TD, Cheung AM, et al. Atypical subtrochanteric and diaphyseal femoral fractures: second report of a task force of the American society for bone and mineral research. J Bone Miner Res. 2014;29(1):1-23.

** Location is a requirement.

patient with one of these subtrochanteric fractures whose iliac crest biopsy was completely normal. Several retrospective studies have also suggested an association between bisphosphonate use and atypical fractures (4144). The association between long term bisphosphonate use and atypical fractures does not prove causality; additional large-scale studies are needed to further clarify this issue.

\section{POSSIBLE "SIDE BENEFITS" OF BISPHOSPHONATE THERAPY}

Not all the news about long-term bisphosphonate use is bad. There is evidence from controlled trials and observational studies that bisphosphonate treatment is associated with a decreased risk of breast cancer (45-48), colorectal cancer (49), gastric cancer (50), stroke (51) and myocardial infarction (52) as well as improved survival $(17,53)$.

\section{DRUG HOLIDAYS}

Bisphosphonates are unique in that the drugs accumulate in bone and there appears to be residual benefit in terms of fracture reduction for some time after a 3 to 5 year course of bisphosphonate treatment (13).

The little data we have suggests that for higher risk patients, continuing treatment for 6-10 years is better than stopping after $3-5$ years $(3,15,54)$. Although the "drug holiday" concept has been widely accepted (55), data are not robust on how long to treat, how long the holiday should be, when the holiday should be stopped or effectiveness of treatment after re-starting. The good news is that a break in bisphosphonate therapy may "reset the clock" on ONJ and AFF. I believe there is logic to support the following scenarios:
1. Fracture risk is mild: bisphosphonate treatment or 3-5 years, then stop. The "drug holiday" can be continued until there is significant loss of BMD (i.e., more than the least significant change as determined by the testing center) or the patient has a fracture, whichever comes first.

2. Fracture risk is moderate: bisphosphonate treatment for about 5 years, offer a "drug holiday" of 3-5 years or until there is significant loss of BMD or the patient has a fracture, whichever comes first.

3. Fracture risk is high: bisphosphonate treatment for 6-10 years, offer a "drug holiday" of 1-2 years, until there is significant loss of BMD or the patient has a fracture, whichever comes first. A non-bisphosphonate treatment (e.g., raloxifene, teriparatide) may be offered during the "holiday" from the bisphosphonate.

It has been suggested that a decrease in BMD or increase in bone turnover marker (BTM) might be used to decide when to end a drug holiday, but the risedronate study showed that fracture risk remained reduced despite what appeared to be unfavorable changes in these parameters (13). Conversely, there is no evidence that, off treatment, fracture risk is reduced if BMD is stable or BTM is low.

\section{CONCLUSIONS}

Bisphosphonates offer a safe and effective treatment to reduce fracture risk, with evidence for "broad spectrum" (i.e., spine, hip and non-vertebral) fracture risk reduction not shown for other available agents. They can be administered orally (daily, weekly or monthly) or intravenously (quarterly or yearly). Since their initial introduction in the US in 1995, questions have been raised about their 
association with possible side effects (osteonecrosis of the jaw, musculoskeletal pain, atrial fibrillation, atypical fractures, esophageal cancer) that appear to be rare and may not be causally related. For most patients with osteoporosis, the benefits of treatment outweigh the risks.

Because bisphosphonates are avidly bound to bone, a reservoir of drug accumulates after years of treatment that is gradually released over months or years and appears to result in a lingering anti-fracture benefit for some time after therapy is stopped. This makes it possible to consider "drug holidays" - time off bisphosphonate therapy (but possibly on another agent) - and then resuming therapy. Although there is no strong science to guide us, we believe that some time off treatment should be offered to most patients on long-term bisphosphonate therapy. The duration of treatment and the length of the "holiday" should be tailored to individual patient circumstances, including the risk of fracture and the binding affinity of the particular bisphosphonate used.

Disclosures: stock options/holdings, royalties, company owner, patent owner, official role: OsteoDynamics, co-founder, stockholder and director. I have received honoraria for lectures from the following companies in the past year. Amgen, Merck. I have received consulting fees from the following companies in the past year: AbbVie, Amarin, Amgen, Bristol-Meyers Squibb, Corcept, Endo, Imagepace, Janssen, Lilly, Merck, Novartis, Noven, Pfizer/Wyeth, Radius, Sanofi-Aventis. Through my Health System, I have research support from the following companies: Merck, NPS.

\section{REFERENCES}

1. Russell RGG, Rogers MJ. Bisphosphonates: from the laboratory to the clinic and back again. Bone. 1999;25(1):97-106.

2. Bone HG, Hosking D, Devogelaer JP, Tucci JR, Emkey RD, Tonino $\mathrm{RP}$, et al. Ten years' experience with alendronate for osteoporosis in postmenopausal women. New Engl J Med. 2004;350(12):1189-99.

3. Black DM, Schwartz AV, Ensrud KE, Cauley JA, Levis S, Quandt $\mathrm{SA}$, et al. Effects of continuing or stopping alendronate after 5 years of treatment: the Fracture Intervention Trial Long-term Extension (FLEX): a randomized trial. JAMA. 2006;296(24):2927-38.

4. Black DM, Cummings SR, Karpf DB, Cauley JA, Thompson DE, Nevitt MC, et al. Randomised trial of effect of alendronate on risk of fracture in women with existing vertebral fractures. Fracture Intervention Trial Research Group. Lancet. 1996;348(9041):1535-41.

5. Harris ST, Watts NB, Genant HK, McKeever CD, HangartnerT, Keller $\mathrm{M}$, et al. Effects of risedronate treatment on vertebral and nonvertebral fractures in women with postmenopausal osteoporosis: a randomized controlled trial. Vertebral Efficacy With Risedronate Therapy (VERT) Study Group. JAMA. 1999;282(14):1344-52.

6. Black DM, Delmas PD, Eastell R, Reid IR, Boonen S, Cauley JA, et al. Once-yearly zoledronic acid for treatment of osteoporosis. N Engl J Med. 2007;356(18):1809-22.

7. Adami S, Bhalla AK, Dorizzi R, Montesanti F, Rosini S, Salvagno G, et al. The acute phase response after bisphosphonate administration. CalcifTissue Int. 1987;41(6):326-31.
8. Gallacher SJ, Ralston SH, Patel U, Boyle IT. Side-effects of pamidronate. Lancet. 1989;2(8653):42-3.

9. Zojer N, Keck AV, Pecherstorfer M. Comparative tolerability of drug therapies for hypercalcaemia of malignancy. Drug Saf. 1999;21(5):389-406.

10. Maalouf NM, Heller HJ, Odvina CV, Kim PJ, Sakhaee K. Bisphosphonate-induced hypocalcemia: report of 3 cases and review of literature. Endocr Pract. 2006;12(1):48-53.

11. Miller PD, Roux C, Boonen S, Barton IP, Dunlap LE, Burgio DE. Safety and efficacy of risedronate in patients with age-related reduced renal function as estimated by the Cockcroft and Gault method: a pooled analysis of nine clinical trials. J Bone Miner Res. 2005;20(12):2105-15.

12. Jamal SA, Bauer DC, Ensrud KE, Cauley JA, Hochberg M, Ishani $A$, et al. Alendronate treatment in women with normal to severely impaired renal function: an analysis of the fracture intervention trial. J Bone Miner Res. 2007;22(4):503-8.

13. Watts NB, Chines A, Olszynski WP, McKeever CD, McClung MR, Zhou $X$, et al. Fracture risk remains reduced one year after discontinuation of risedronate. Osteoporos Int. 2008;19(3):365-72.

14. Mellström DD, Sörensen $\mathrm{OH}$, Goemaere $\mathrm{S}$, Roux $\mathrm{C}$, Johnson TD, Chines AA. Seven years of treatment with risedronate in women with postmenopausal osteoporosis. Calcif Tissue Int. 2004;75(6):462-8.

15. Black DM, Reid IR, Boonen S, Bucci-Rechtweg C, Cauley JA, Cosman $F$, et al. The effect of 3 versus 6 years of zoledronic acid treatment of osteoporosis: a randomized extension to the HORIZON-Pivotal Fracture Trial (PFT). J Bone Miner Res. 2012;27(2):243-54.

16. Wysowski DK, Chang JT. Alendronate and risedronate: reports of severe bone, joint, and muscle pain. Arch Intern Med. 2005;165(3):346-7.

17. Lyles KW, Colon-Emeric CS, Magaziner JS, Adachi JD, Pieper CF, Mautalen $\mathrm{C}$, et al. Zoledronic acid and clinical fractures and mortality after hip fracture. N Engl J Med. 2007;357:1799-809.

18. Loke YK, Jeevanantham V, Singh S. Bisphosphonates and atrial fibrillation: systematic review and meta-analysis. Drug Saf. 2009;32(3):219-28.

19. Grosso A, Douglas I, Hingorani A, MacAllister R, Smeeth L. Oral bisphosphonates and risk of atrial fibrillation and flutter in women: a self-controlled case-series safety analysis. PLoS One. 2009;4(3):e4720.

20. Barrett-Connor E, Swern AS, Hustad CM, Bone HG, Liberman UA, Papapoulos S, et al. Alendronate and atrial fibrillation: a meta-analysis of randomized placebo-controlled clinical trials. Osteoporos Int. 2012;23(1):233-45.

21. Rhee CW, Lee J, Oh S, Choi NK, Park BJ. Use of bisphosphonate and risk of atrial fibrillation in older women with osteoporosis. Osteoporos Int. 2012;23(1):247-54.

22. Wysowski DK. Reports of esophageal cancer with oral bisphosphonate use. (letter). N Engl J Med. 2009;360(1):89-90.

23. Siris ES, Oster MW, Bilezikian JP. More on reports of esophageal cancer with oral bisphosphonate use (letter). N Engl J Med. 2009;360(1791).

24. Shaheen NJ. More on reports of esophageal cancer with oral bisphosphonate use (letter). N Engl J Med. 2009;360:1790-1.

25. Abrahamsen B, Eiken P, Eastell R. More on reports of esophageal cancer with oral bisphosphonate use (letter). N Engl J Med. 2009; 360(1789).

26. Solomon DH, Patrick A, Brookhart MA. More on reports of esophageal cancer with oral bisphosphonate use (letter). N Engl J Med. 2009;360:1789-90.

27. Hofbauer LC, Miehlke S. More on reports of esophageal cancer with oral bisphosphonate use (letter). $\mathrm{N}$ Engl J Med. 2009;360:1790. 
28. Robins $\mathrm{HI}$, Holen KD. More on reports of esophageal cancer with oral bisphosphonate use (letter). N Engl J Med. 2009;360:1790.

29. Cardwell CR, Abnet CC, Cantwell MM, Murray LJ. Exposure to oral bisphosphonates and risk of esophageal cancer. JAMA. 2010;304(6):657-63.

30. Green J, Czanner G, Reeves G, Watson J, Wise L, Beral V. Oral bisphosphonates and risk of cancer of oesophagus, stomach, and colorectum: case-control analysis within a UK primary care cohort. BMJ 2010;341:c4444.

31. Marx RE. Pamidronate (Aredia) and zoledronate (Zometa) induced avascular necrosis of the jaws: a growing epidemic (letter). J Oral Maxillofac Surg. 2003;61(9):1115-7.

32. Ruggiero SL, Mehrotra B, Rosenberg TJ, Engroff SL. Osteonecrosis of the jaws associated with the use of bisphosphonates: a review of 63 cases. J Oral Maxillofac Surg. 2004;62(5):527-34.

33. Woo S-B, Hellstein JW, Kalmar JR. Systematic review: bisphosphonates and osteonecrosis of the jaws. Ann Intern Med. 2006;144(10):753-61.

34. Khosla S, Burr D, Cauley J, Dempster DW, Ebeling PR, Felsenberg $\mathrm{D}$, et al. Bisphosphonate-associated osteonecrosis of the jaw: report of a task force of the American Society for Bone and Mineral Research. J Bone Miner Res. 2007;22(10):1479-91.

35. Triester N, Woo SB. Bisphosphonate-associated osteonecrosis of the jaw. N Engl J Med. 2006; 335:2348.

36. Bilezikian JP. Osteonecrosis of the jaw--do bisphosphonates pose a risk? N Engl J Med. 2006;355(22):2278-81.

37. Black DM, Boonen S, Cauley J et al. Effect of once-yearly infusion of zoledronic acid $5 \mathrm{mg}$ on spine and hip fracture reduction in postmenopausal women with osteoporosis: the HORIZON pivotal fracture trial (abstract). J Bone Miner Res 2006; 21 (suppl 1):S16.

38. 2006 Annual Report IMS HEALTh. NPA Plus May 2006.

39. Saad F, Brown JE, Van Poznak C, Ibrahim T, Stemmer SM, Stopeck AT, et al. Incidence, risk factors, and outcomes of osteonecrosis of the jaw: integrated analysis from three blinded active-controlled phase III trials in cancer patients with bone metastases. Ann Oncol. 2012;23(5):1341-7.

40. Hellstein JW, Adler RA, Edwards B, Jacobsen PL, Kalmar JR, Koka $\mathrm{S}$, et al. Managing the care of patients receiving antiresorptive therapy for prevention and treatment of osteoporosis: executive summary of recommendations from the American Dental Association Council on Scientific Affairs. J Am Dent Assoc. 2011;142(11):1243-51.

41. Goh SK, Yang KY, Koh JS, Wong MK, Chua SY, Chua DT, et al. Subtrochanteric insufficiency fractures in patients on alendronate therapy: a caution. J Bone Joint Surg Br. 2007;89(3):349-53.

42. Neviaser AS, Lane JM, Lenart BA, Edobor-Osula F, Lorich DG. Low-energy femoral shaft fractures associated with alendronate use. J Orthop Trauma. 2008;22(5):346-50.
43. Lenart BA, Neviaser AS, Lyman S, Chang CC, Edobor-Osula F, Steele $B$, et al. Association of low-energy femoral fractures with prolonged bisphosphonate use: a case control study. Osteoporos Int. 2009;20(8):1353-62.

44. Park-Wyllie LY, Mamdani MM, Juurlink DN, Hawker GA, Gunraj $\mathrm{N}$, Austin PC, et al. Bisphosphonate use and the risk of subtrochanteric or femoral shaft fractures in older women. JAMA. 2011;305(8):783-9.

45. Vestergaard P, Fischer L, Mele M, Mosekilde L, Christiansen P. Use of bisphosphonates and risk of breast cancer. Calcif Tissue Int. 2011;88(4):255-62.

46. Dreyfuss JH. Oral bisphosphonate use associated with a decreased risk of breast cancer. Cancer 2010;60:343-44.

47. Chlebowski RT, Chen Z, Cauley JA, Anderson G, Rodabough RJ, McTiernan A, et al. Oral bisphosphonate use and breast cancer incidence in postmenopausal women. J Clin Oncol. 2010;28(22):3582-90.

48. Rennert G, Pinchev M, Rennert HS. Use of bisphosphonates and risk of postmenopausal breast cancer. J Clin Oncol. 2010;28(22):3577-81.

49. Rennert G, Pinchev M, Rennert HS, Gruber SB. Use of bisphosphonates and reduced risk of colorectal cancer. J Clin Oncol. 2011;29(9):1146-50.

50. Abrahamsen B, Pazianas M, Eiken P, Russell RG, Eastell R. Esophageal and gastric cancer incidence and mortality in alendronate users. J Bone Miner Res. 2012;27(3):679-86.

51. Steinbuch M, D'Agostino RB, Mandel JS, Gabrielson E, McClung MR, Stemhagen A, et al. Assessment of mortality in patients enrolled in a risedronate clinical trial program: a retrospective cohort study. Regul Toxicol Pharmacol. 2002;35(3):320-6.

52. Wolfe F, Bolster MB, O'Connor CM, Michaud K, Lyles KW, Colón-Emeric CS. Bisphosphonate use is associated with reduced risk of myocardial infarction in patients with rheumatoid arthritis. $J$ Bone Miner Res. 2013;28(5):984-91.

53. Grey A, Bolland MJ. The effect of treatments for osteoporosis on mortality. Osteoporos Int. 2013;24(1):1-6.

54. Schwartz AV, Bauer DC, Cauley JA, et al. Efficacy of continued alendronate for fractures in women without prevalent vertebral fracture:The FLEX trial (abstract). J Bone Miner Res. 2007;22 (suppl 1):S16-7.

55. Whitaker M, Guo J, Kehoe T, Benson G. Bisphosphonates for osteoporosis--where do we go from here? N Engl J Med. 2012;366(22):2048-51.

56. Watts NB, Diab DL. Long-term use of bisphosphonates in osteoporosis. J Clin Endocrinol Metab. 2010;95(4):1555-65.

57. Armamento-Villareal R, Napoli N, Diemer K, Watkins M, Civitelli $\mathrm{R}$, Teitelbaum S, et al. Bone turnover in bone biopsies of patients with low-energy cortical fractures receiving bisphosphonates: a case series. CalcifTissue Int. 2009;85(1):37-44. 